\title{
IMPACT OF MICROWAVE AND AUTOCLAVE DECONTAMINATION ON PASTRAMI QUALITY AND TRACKING CCPS
}

\author{
Rehab M. El-Mougy ${ }^{1 *} ;$ A. M. El-Shawaf ${ }^{1}$; A. El-Makhzangy ${ }^{1}$; S. M. Abd- \\ Elghany ${ }^{2}$ \\ 1. Department of Food and Dairy Science, Faculty of Technology and \\ Development, Zagazig University, Egypt. \\ 2. Department of Food Hygiene and Control, Faculty of Veterinary Medicine, \\ Mansoura University, Mansoura 35516, Egypt. \\ *All corresponding address to elmougy2005@hotmail.com
}

\begin{abstract}
The goal of current research is determining the impact of ingredients decontamination using microwave and autoclave on pastrami final product, which finally leads us to track CCPs along the manufacture process to get final product of zero defects. The research focused on pastrami product as a famous widely used dry-cured meat product in the Egyptian market. The raw meat that used in pastrami production was purchased in three forms; fresh, frozen, and chilled meat from Egyptian market (local market in Mansoura city). The pastrami was manufactured in two groups; the first group was produced via microwave sterilization for 60 seconds of all non-meat ingredients with submission of wholesome circumstances, and the second group was fabricated through autoclave sterilization $\left(120^{\circ} \mathrm{C}\right.$ for $15 \mathrm{~min}$ ) of all constituents with application of sanitary conditions. The pastrami was examined along the manufacture process for total viable count (TVBC) and E. coli. The final product of each group was inspected for mold and yeast presence. Another group of pastrami was manufactured using frozen meat (imported from Brazil) only with applying three spices treatments. The first treatment was pastrami production without any spices addition. The second treatment was pastrami fabrication using spices which were purchased from local spices shops and subjected to autoclave sterilization $\left(120^{\circ} \mathrm{C}\right.$ for 15 min). The third treatment was pastrami manufacture using high quality spices which were bought from reliable supplier and underwent to autoclave disinfection $\left(120^{\circ} \mathrm{C}\right.$ for $\left.15 \mathrm{~min}\right)$. The final product of each sample was checked for occurrence of aflatoxins. Sensory evaluation of the best product from microbiological aspect was carried out. The best-fabricated group from microbiological
\end{abstract}


aspect was the second autoclaved one. For pastrami group that was fabricated via three different spices treatments, the first treatment indicates that the raw meat itself contain a certain level of aflatoxin. The second treatment comprises very high unacceptable limit of aflatoxin. The third treatment (meat manufactured using high quality spices from reliable supplier) is the most compatible one with permissible aflatoxin limit in meat products $(20 \mathrm{ppb})$. The sensory evaluation of autoclaved group revealed that the pastrami final product is wholly accepted except the pastrami produced using frozen raw meat had low rating for color and texture.

Key words: Pastrami, manufacture, dry curing, spices, decontamination, microwave, autoclave, meat, aflatoxins, CCPs.

\section{INTRODUCTION}

It was proven that meat-processing sector is an important fraction of overall economy advancement for any country. The meat-processing sector has the ability to produce variable meat products that participates in providing job opportunities and enhance manufacturers' income (Panghal et $a l ., 2018)$. Therefore, we have to find the best methods to produce high quality meat products of zero defects in order to assist manufacturers and owners of meat-processing plants to produce high quality products.

The research adopted pastrami as one of unique dry-cured, nonthermally heated and fermented well-known and widely used meat products in Egypt and Middle East (Erdemir and Aksu, 2017). Pastramă is a Romanian word means keep or preserve. It may be originated from Latin word pastor denotes shepherd's meat of sheep. It is manufactured from whole muscles ( $M$. Longissimus dorsi) of beef or buffalo (Daniela and Adrian 2015; Karabiyıklı et al., 2015).

Pastırma is originated from Turkish verb "bastırma" which means stress. The period of pastrami production takes about one month according to meat cuts size (Kilic, 2009). The pastrami final product is of high nutritional value contains about $30 \%$ protein, $45 \%$ moisture, $15 \%$ fat with serviceable shelf life more than 3 months (Aksu and Kaya, 2001).

Pastrami is defined in ESS (2005/1042) as dry-cured meat product treated by nitrite or nitrate salts, seasoned and coated with garlic and fenugreek (ESS, 2005/1042). The used additives in salting and curing of pastrami are so effective in pastrami quality. Table salt with nitrate or nitrite with some other chemicals and different type of spices are used in meat curing (Aksu et al., 2015). 
Therefore, the research goal is to find the best method of sterilization along manufacture process of pastrami through studying the impact of microwave sterilization, and autoclave sanitation of used ingredients on final product microbiological quality, and aflatoxin contents. Hence, it became so easy to identify CCPs along the manufacture course.

\section{MATEIALS AND METHODS}

\section{Materials}

\section{1) Meat Cuts:}

The longismus dorsi muscle of beef was bought from Mansoura local market (frozen, fresh, and chilled). All meat cuts were handled under strict hygienic conditions using gloves, sterile knives, containers, and transmitted using icebox.

\section{2) Table salt:}

The table salt was purchased from local markets in Mansoura city from local Egyptian company.

\section{3) Water:}

The water used for meat washing in both microwaved and autoclaved group is sterilized water. Distilled water was used for laboratory tasks.

\section{4) Spices:}

The used spices were clove (Syzygium aromaticum), nutmeg (myristica fragrans), coriander (Coriandrum sativum), and black pepper (Piper guineense)]. They were purchased from Mansoura local spice shops. Another similar collection of spices was bought from reliable Egyptian company and subjected to HACCP measures in its production.

\section{5) Sodium Nitrite:}

The used sodium nitrite is food grade E250 produced in Germany by BASF Aktiengesellschaft Company and imported to Egypt by the importer AWA Company. ESS/2005 recommended adding sodium nitrite by $100 \mathrm{ppm} / 1 \mathrm{~kg}$ meat.

\section{6) Ascorbic Acid:}

The used ascorbic acid was bought from El-Gomhuoria Company for Trading Chemicals and Medical Appliances, Mansoura branch. It was added by 550ppm/1kg meat (Robach and Sofos, 1982; Sullivan, 2011). 


\section{7) Sweeteners:}

The used brown sugar was bought from local markets at Mansoura city. Molasses was purchased from El-Dakahlia Company for Sugar Production. The sweeteners are self-determining and there are no specific regulations to add them. They were added in accordance with modified recipe as mentioned below.

\section{8) Rosemary extract:}

The rosemary was bought from Mansoura local market and another quantity was bought from reliable supplier. The obtained rosemary leaves were washed with running tape water, dried by air in shade at room temperature for one week. The dried leaves were powdered. After that, 50 $\mathrm{ml}$ of ethanol was added to $5 \mathrm{gm}$ of rosemary powder and mixed in a sterile flask. The flask was shaked, centrifuged and filtered (Bibi and Mahnoor, 2014).

\section{9) Nutmeg extract:}

The nutmeg was bought from local market of Mansoura city and another quantity was bought from reliable supplier. The ethanolic extract of nutmeg was prepared via the same protocol used for rosemary.

\section{0) Sweet and hot pepper puree:}

Sweet (Capsicum annuum) and hot pepper (Capsicum baccatum) were used in seasoning paste (çemen) applied on pastrami in the form of puree. The puree was prepared according to Sharoba (2009).

\section{1) Garlic:}

The fresh garlic (Allium sativum L.) cloves were bought from local market of Mansoura city, Dakalia governorate, Egypt. It was smashed and then acidified using 3\% citric acid for 24 hrs (Barbara et al., 2014).

\section{2) Fenugreek flour:}

The fenugreek (Trigonella foenum graecum) seeds were obtained from local market at Mansoura city. The seeds were thoroughly washed and dried then the seed were roasted in an open pan at $130 \pm 5^{\circ} \mathrm{C}$ for 7 minutes. Then they crushed in Moulinex Odacio FP7361BM (Pandey and Awasthi, 2015). The resulted fenugreek flour was used in pastrami seasoning paste by $500 \mathrm{~g} / 1 \mathrm{Kg}$ meat according to Aksu et al. (2017). 


\section{3) Equipment:}

Autoclave, Incubator, Grinder Moulinex Odacio FP7361BM, Stainless steel trays, Gauze, Needle, strengthen Cotton thread, suitable weight and plastic stretch filament.

\section{Methods}

\section{1) Pastrami Recipe:}

The quantities used in pastrami recipe was carried out in accordance with Aksu et al. (2017) with some modifications.

Quantities of pastrami original recipe by Aksu et al. (2017)

\begin{tabular}{lc}
\hline Ingredients & Concentration /1000 gm meat \\
\hline Table salt & $50 \mathrm{gm}$ \\
Sodium nitrite & $0.1 \mathrm{gm}$ \\
Fenugreek Powder & $500 \mathrm{gm}$ \\
Smashed garlic & $350 \mathrm{gm}$ \\
Powdered hot pepper & $75 \mathrm{gm}$ \\
Powdered paprika & $75 \mathrm{gm}$ \\
Water & $1000 \mathrm{Ml}$ \\
\hline
\end{tabular}

\section{Applied modifications on used quantities:}

One ounce of curing mixture per one pound of pork meat should be used for dry curing (Ray, 2004). In this experiment, such quantity of dry mixture was applied on used beef meat cuts with the same salt quantity used by Asku et al. (2017) with some modifications in recipe by adding spices made for giving flavour and antimicrobial impact. It means that we shall use $62.5 \mathrm{gm}$ of curing mixture for $1 \mathrm{~kg}$ meat.

Modified composition of pastrami dry curing mixture according to authors:

\begin{tabular}{lc}
\hline Ingredients & Concentration /1000 gm meat \\
\hline Table Salt & 50 \\
Sodium Nitrite & 0.1 \\
Ascorbic acid & 0.4 \\
Brown Sugar & 2 \\
Molasses & 2 \\
Coriander & 2 \\
Black pepper & 2 \\
Clove & 2 \\
Nutmeg & 2 \\
\hline
\end{tabular}


Modified composition of seasoning paste according to authors:

\begin{tabular}{lc}
\hline Ingredients & Concentration $/ \mathbf{1 0 0 0} \mathbf{~ g m ~ m e a t ~}$ \\
\hline Fenugreek flour & $500 \mathrm{gm}$ \\
Smashed garlic & $350 \mathrm{gm}$ \\
Sweet RP (puree) & $50 \mathrm{gm}$ \\
Hot RP (puree) & $50 \mathrm{gm}$ \\
Table salt & $20 \mathrm{gm}$ \\
Powdered clove & $10 \mathrm{gm}$ \\
Powdered coriander & $10 \mathrm{gm}$ \\
Powdered BP & $10 \mathrm{gm}$ \\
Rosemary EE & $100 \mathrm{~mL}$ \\
Nutmeg EE & $100 \mathrm{~mL}$ \\
Water & $800 \mathrm{~mL}$ \\
\hline
\end{tabular}

EE: Ethanolic extract, RP: Red pepper, BP: Black pepper.

\section{2) Pastrami manufacture:}

All steps were implemented according with Aksu et al. (2017) and Kaban (2013) as follows:

- Meat Preparation: via removal of excessive tendons, fat or connective tissues.

- Dry Curing: many cervices and holes were made in meat cuts to assist curing mixture accessing meat depth. The curing mixture was distributed to put on meat surface and penetrate incisions made in meat. Salted meats were kept at $6^{\circ} \mathrm{C}$ for $48 \mathrm{hrs}$.

- $\mathbf{1}^{\text {st }}$ Drying: Cured meats for pastrami were slightly washed and then dried at $15^{\circ} \mathrm{C}$ for 4 days.

- $1^{\text {st }}$ Pressing: cured and dried meat cuts were pressed using weight. Pressing was executed at $7-10^{\circ} \mathrm{C}$ for $17 \mathrm{hrs}$.

- $2^{\text {nd }}$ Drying: meat cuts were redried for 3-4 days in $20^{\circ} \mathrm{C}$.

- $2^{\text {nd }}$ Pressing: it was performed at $25^{\circ} \mathrm{C}$ for $7 \mathrm{hrs}$.

- Addition of Seasoning Paste (çemen): meat cuts were covered with slurry like seasoning paste (çemen) and kept at $7^{\circ} \mathrm{C}$ for $4-5$ days.

- Final Drying: After the addition of seasoning paste, meat cuts were finally dried at $20^{\circ} \mathrm{C}$ for $4-5$ days.

The whole manufacture process is preferable to be carried out in late September to October and November as the relative humidity must be lower than $75 \%$ in drying and pressing chambers also fans must be utilized to improve air movement system in drying and pressing chambers (Asefa et al., 2011).

3) Manufactured groups of pastrami:

The raw meat (fresh, frozen, and chilled) was manufactured in two groups as follows: 
- First Group was prepared under full wholesome conditions. The spices, puree, extract, water, and fenugreek powder were sterilized using microwave P100 (with full power of microwave) for 60 seconds.

- Second Group was fabricated under complete sanitary conditions. The spices, puree, extract, water, and fenugreek powder were sterilized using autoclave at $120^{\circ} \mathrm{C}$ for $15 \mathrm{~min}$.

Specific Group manufactured (from frozen raw meat) with three treatments of spices:

- $I^{\text {st }}$ treatment: pastrami production without any spices addition.

- $2^{\text {nd }}$ treatment: pastrami fabrication using spices which were purchased from local spices shops and subjected to autoclave sterilization $\left(120^{\circ} \mathrm{C}\right.$ for $15 \mathrm{~min})$.

- $3^{\text {rd }}$ treatment: pastrami manufacture using spices which were bought from reliable supplier and underwent to autoclave disinfection $\left(120^{\circ} \mathrm{C}\right.$ for 15 $\min )$.

\section{4) Laboratory tests:}

\section{A) Microbiological analysis:}

a. Total viable bacterial count (TVBC):

The $T V B C$ assessment was carried out pursuant to Hayes and Forsythe (2013) using nutrient agar plate count.

b. E. coli strain count:

E.coli was determined in accordance with Aksu et al. (2008) using MacoConky agar media ( $\mathrm{pH} 7.1 \pm 0.2)$ (Oxoid).

\section{c. Yeast and mould count:}

Yeast and mold were identified according to Ozturk (2015) using Dichloran Rose Bengal Chloramphenicol Agar (ISO) and Dichloran 18\% (pH $5.6 \pm 0.2$ at $25^{\circ} \mathrm{C}$ ).

\section{B) Aflatoxin assessment in pastrami final product:}

The final pastrami product was tested for presence of aflatoxins using Vicam AflaTest Fluorometer according to Abd-Elghany and Sallam (2015). The used device was VICAM4- 1107-103606.

\section{C) Sensory analysis of pastrami final product:}

The Pastrami final product were cut into slices $(1.5 \mathrm{~cm})$ used for sensory analysis. Some students of Food and Dairy Science Department were selected and asked to evaluate samples in terms of colour, odour, taste, texture and general acceptability parameters. The evaluation was completed using a hedonic-type scale (1-9 scales: 1: dislike extremely - 9: like extremely) (Ahmet et al., 2018). 


\section{D) Statistical analysis:}

The data collected were presented as mean standard deviation and were analyzed using COSTAT computer software program version 6.0 as one-way analysis of variance (Wright et al., 2005).

\section{RESULTS AND DISCUSSION}

\section{1. $T V B C$ and $E$. coli strains count:}

In $1^{\text {st }}$ group, the dry curing mixture is sterilized using microwave P100 for 60 seconds. The data presented in Table (1) and Fig. (1) indicates that there was a significant difference $(\mathrm{P}<0.05)$ in total viable count along the production stages of pastrami manufacture made of microwaved sterilized ingredients. The $T V B C$ was slightly decreased after addition of dry curing mixture to be $\left(5.51,5.09\right.$, and $\left.5.34 \log _{10} \mathrm{CFUg}_{-1}\right)$ in fresh, frozen, and chilled samples respectively. The TVBC was fluctuated during drying and pressing stages due to temperature oscillation. This result is compatible with findings of Brodowska et al. (2014). They proposed that the method using electromagnetic waves of microwave is effective against vegetative forms of bacteria and fungi, but the endospore forms of Bacillus sp. and Clostridium sp. bacteria and mold spores show a high level of resistance. Brodowska et al. (2014) also reported that the use of microwaves causes insignificant decline in the microorganism count with synchronized huge losses of EOs and variations of their chemical components.

Table (1). TVBC $\left(\log _{10} \mathrm{CFUg}^{-1}\right)$ of pastrami product made of fresh, frozen, and chilled raw meat using microwaved ingredients.

\begin{tabular}{|c|c|c|c|}
\hline Stage of Production & Fresh sample & Frozen sample & Chilled sample \\
\hline Raw meat & $6.2175^{\mathrm{a}}$ & $5.8925^{\mathrm{a}}$ & $6.065^{\mathrm{a}}$ \\
\hline After Dry Curing & $5.51^{\mathrm{bcd}}$ & $5.09^{\mathrm{bc}}$ & $5.3475^{\mathrm{bc}}$ \\
\hline After $1^{\text {st }}$ Drying & $5.715^{\mathrm{bc}}$ & $5.35^{\mathrm{abc}}$ & $5.58^{\mathrm{bc}}$ \\
\hline After $1^{\text {st }}$ Pressing & $5.185^{\mathrm{d}}$ & $4.8525^{\mathrm{c}}$ & $5.085^{\mathrm{c}}$ \\
\hline After $2^{\text {nd }}$ Drying & $5.375^{\mathrm{cd}}$ & $5.2125^{\mathrm{abc}}$ & $5.45 b^{c}$ \\
\hline After $2^{\text {nd }}$ Pressing & $5.6675^{\mathrm{bc}}$ & $5.6^{\mathrm{ab}}$ & $5.5825^{\mathrm{bc}}$ \\
\hline After Addition of Seasoning & $5.855^{\mathrm{b}}$ & $5.7875^{\mathrm{ab}}$ & $5.73^{\mathrm{ab}}$ \\
\hline Final Drying & $5.5275^{\text {bcd }}$ & $5.37^{\mathrm{abc}}$ & $5.4525^{\mathrm{bc}}$ \\
\hline LSD 0.05 & 0.2875 & 0.4739 & 0.3448 \\
\hline
\end{tabular}

Mean values within a column followed with different superscripts are significantly different $(\mathrm{P}<0.05)$.

As well as, there was a significant difference $(\mathrm{P}<0.05)$ in $T V B C$ after addition of seasoning paste to be $\left(5.855,5.7875\right.$, and $\left.5.73 \log _{10} \mathrm{CFUg}^{-1}\right)$ in 


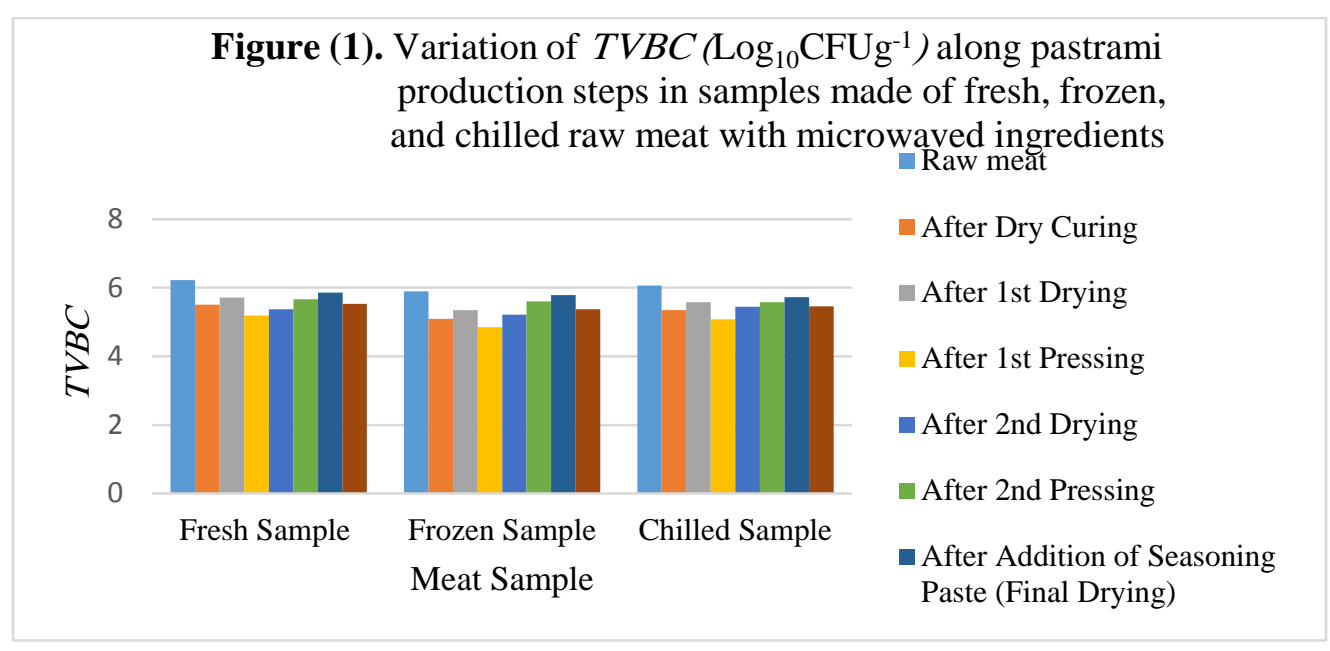

fresh, frozen, and chilled samples respectively which confirm the ineffectiveness of microwave utilization in spices and components decontamination. After final drying, there was a significant difference $(\mathrm{P}<0.05)$ in TVBC to be $\left(5.5275,5.37,5.4525\right.$ and $\left.5.73 \log _{10} \mathrm{CFUg}^{-1}\right)$ in fresh, frozen, and chilled samples respectively. Hence, the TVBC was above the permissible limit in final product as it must not be more than $10^{4}$ Cell/gm in ESS (2005).

In E. coli strains, Table (2) and Fig. (2) showed that there was a significant difference $(\mathrm{P}<0.05)$ in $E$. coli count in the manufactured samples as the $E$. coli count $\left(\log _{10} \mathrm{CFUg}^{-1}\right)$ was slightly decreased in each sample after addition of dry curing mixture to be $(1.8125,1.1575$, and 1.375 $\log _{10} \mathrm{CFUg}^{-1}$ ) in fresh, frozen, and chilled samples respectively. During the drying and pressing stages, the E. coli count was fluctuated according to temperature applied in each stage. The higher the temperature the greater the E. coli count. These findings are matched with what reported by Canumir et al. (2002). They reported that microwave treatment could reduce E. coli population by 2-4 $\log$ due to effect of heat. Hence, microwave is not sufficient to eliminate $E$. coli completely from spices especially if they had high count.

Therefore, insufficient decontaminated spices, E. coli count located originally in meat, and processing temperature participated in presence of $E$. coli along the stages of curing, drying, and pressing. These results are also partially compatible with what found by Ingham et al. (2006) that the Drycuring and drying are potentially so essential pathogen-reduction steps because drying was implemented under different temperatures along with 
Table (2). E. coli strains count $\left(\log _{10} \mathrm{CFUg}^{-1}\right)$ of pastrami product made of fresh, frozen, and chilled raw meat using microwaved ingredients.

\begin{tabular}{lccc}
\hline Stage of Production & $\begin{array}{l}\text { Fresh } \\
\text { sample }\end{array}$ & $\begin{array}{l}\text { Frozen } \\
\text { sample }\end{array}$ & $\begin{array}{l}\text { Chilled } \\
\text { sample }\end{array}$ \\
\hline Raw meat & $1.8925^{\mathrm{a}}$ & $1.56^{\mathrm{a}}$ & $1.7675^{\mathrm{a}}$ \\
After Dry Curing & $1.8125^{\mathrm{a}}$ & $1.1575^{\mathrm{ab}}$ & $1.375^{\mathrm{ab}}$ \\
After 1 $1^{\text {st }}$ Drying & $1.79^{\mathrm{a}}$ & $0.775^{\mathrm{ab}}$ & $1.225^{\mathrm{ab}}$ \\
After 1 $^{\text {st }}$ Pressing & $1.1975^{\mathrm{ab}}$ & $0.6875^{\mathrm{ab}}$ & $0.4975^{\mathrm{bc}}$ \\
After 2 $^{\text {nd }}$ Drying & $0.4975^{\mathrm{bc}}$ & $0.5725^{\mathrm{ab}}$ & $0.5375^{\mathrm{bc}}$ \\
After 2 $2^{\text {nd }}$ Pressing & $0.4975^{\mathrm{bc}}$ & $0.6^{\mathrm{ab}}$ & $0.625^{\mathrm{bc}}$ \\
After Addition of Seasoning Paste & $\mathrm{ND}$ & $\mathrm{ND}$ & $\mathrm{ND}$ \\
Final Drying & $\mathrm{ND}$ & $\mathrm{ND}$ & $\mathrm{ND}$ \\
\hline LSD 0.05 & $\mathbf{0 . 5 8 1 7}$ & $\mathbf{0 . 7 4 8 6}$ & $\mathbf{0 . 6 7 2 9}$ \\
\hline
\end{tabular}

Mean values within a column followed with different superscripts are significantly different $(\mathrm{P}<0.05)$, ND: not detected.

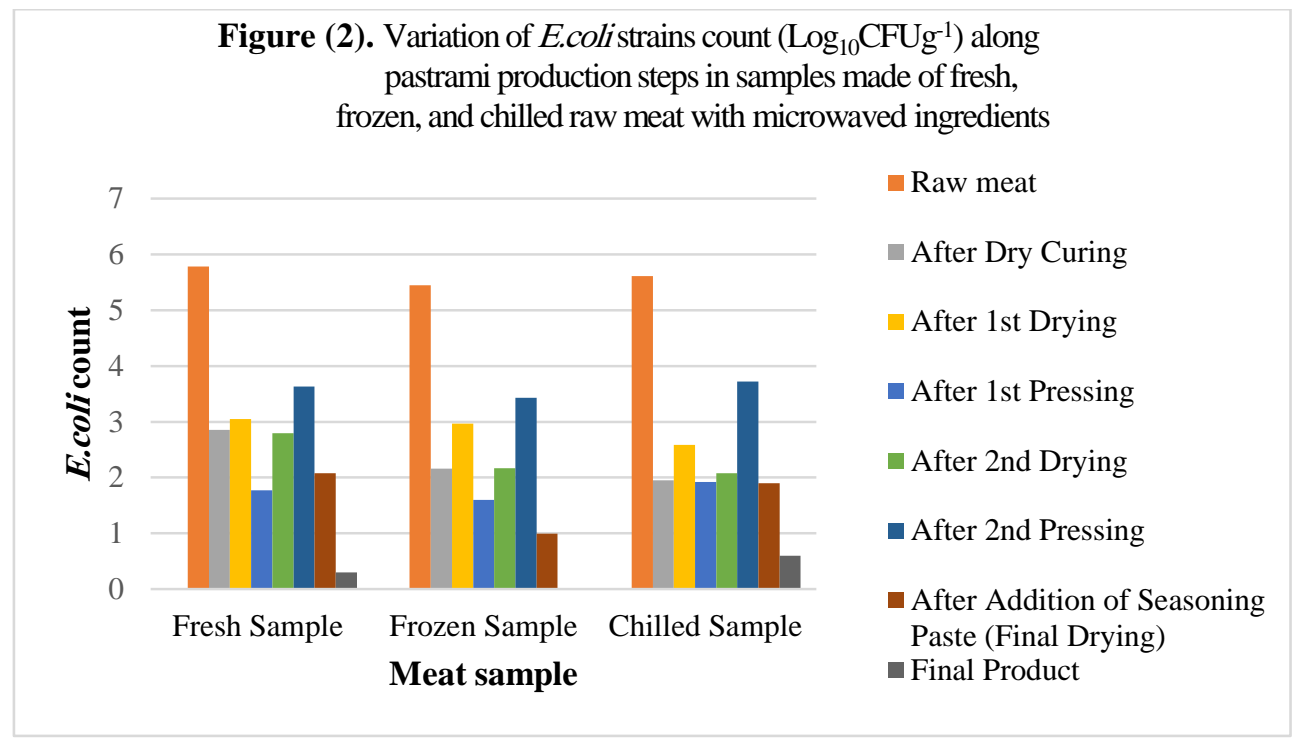

insufficient decontaminated spices, which led to formulate an impact on the microbial count and E.coli. After addition of microwaved seasoning paste and applying final drying, there was a significant difference $(\mathrm{P}<0.05)$ in E.coli count as it was markedly decreased and disappeared in frozen sample. This may be attributed to preserving effect of seasoning paste as confirmed by (Yetim et al., 2006). The E.coli count is compatible with ESS (2005) as pastrami final product must be free from E.coli strains. 
In $2^{\text {nd }}$ group, The manufacture process is executed under complete sterilized conditions with spices and all other ingredients sterilization using autoclave at $120^{\circ} \mathrm{C}$ for 15 minutes. The data presented in Table (3) and Fig. (3) indicates that there was a significant difference $(\mathrm{P}<0.05)$ in total viable count along the production stages of pastrami manufacture made of autoclave sterilized ingredients. The $T V B C$ was significantly decreased after addition of autoclaved sterilized dry curing mixture then rinsed using sterilized water to be $\left(2.855,2.1575\right.$, and $\left.1.95 \log _{10} \mathrm{CFUg}^{-1}\right)$ in fresh, frozen, and chilled samples respectively. The addition of dry curing mixture containing Nacl and sodium nitrite as well as spices led to notable decrease in TVBC. This result is compatible with what reported by King et al. (2014). They reported that the Nacl can solubilize proteins, emulsify fats, control harmful bacteria causing spoilage besides the antimicrobial effect of spices which was proven by many scientists.

There was a significant difference $(\mathrm{P}<0.05)$ in total viable count after applying the drying and pressing stages. This was due to change in temperature in each stage. The higher the temperature the greater the $T V B C$. The notable difference was occurred after carrying out the second stage of pressing at $25^{\circ} \mathrm{C}$ for $7 \mathrm{hrs}$ as the $T V B C$ was elevated due to temperature increse. This is partially compatible with what found by Ingham et al. (2006) that the Dry-curing and drying are potentially so essential pathogenreduction steps because drying and pressing were implemented under different temperatures that led to formulate an impact on the microbial count. This assures that the drying and pressing temperature control must be taken into account as an essential prophylactic procedure to obtain safe pastrami.

After applying the sterilized seasoning paste using autoclave at low temperature $7^{\circ} \mathrm{C}$ for $4-5$ days, $T V B C$ was decreased to be $(2.075,0.9975,1.9$ $\log _{10} \mathrm{CFUg}^{-1}$ ) for fresh, frozen, and chilled samples respectively. After final drying at $20^{\circ} \mathrm{C}$ for $4-5$ days, the microbial count was declined to be $(0.3$, not detected, and $0.6 \log _{10} \mathrm{CFUg}^{-1}$ ) for fresh, frozen, and chilled samples respectively. This result is matched with what assured by Yetim et al. (2006). They found that the paste prepared from ground fenugreek, garlic and red hot pepper, which tested for inhibitory effect on E.coli, S. aureus and $Y$. enterocolitica, showed varying inhibitory effect against all tested bacteria. In addition, the complete seasoning paste are effective against microbes when compared with only one component. This assures the exactitude and correctness of spices, plant extract, and hot and sweet pepper puree in the presented modified recipe of seasoning paste. 
Table (3). TVBC $\left(\log _{10} \mathrm{CFUg}^{-1}\right)$ of pastrami product made of fresh, frozen, and chilled raw meat using autoclaved ingredients.

\begin{tabular}{lccc}
\hline Stage of Production & $\begin{array}{c}\text { Fresh } \\
\text { sample }\end{array}$ & $\begin{array}{c}\text { Frozen } \\
\text { sample }\end{array}$ & $\begin{array}{c}\text { Chilled } \\
\text { sample }\end{array}$ \\
\hline Raw meat & $5.7825^{\mathrm{a}}$ & $5.45^{\mathrm{a}}$ & $5.61^{\mathrm{a}}$ \\
After Dry Curing & $2.855^{\mathrm{bc}}$ & $2.1575^{\mathrm{bc}}$ & $1.95^{\mathrm{bc}}$ \\
After 1 $1^{\text {st }}$ Drying & $3.0475^{\mathrm{bc}}$ & $2.97^{\mathrm{b}}$ & $2.5825^{\mathrm{bc}}$ \\
After 1 $1^{\text {st }}$ Pressing & $1.775^{\mathrm{c}}$ & $1.6^{\mathrm{bcd}}$ & $1.9225^{\mathrm{bc}}$ \\
After 2 & $2.795 \mathrm{~b}^{\mathrm{c}}$ & $2.17 \mathrm{~b}^{\mathrm{c}}$ & $2.0775^{\mathrm{bc}}$ \\
After 2 $2^{\text {nd }}$ Pressing & $3.6325^{\mathrm{b}}$ & $3.4275^{\mathrm{b}}$ & $3.72^{\mathrm{b}}$ \\
After Addition of Seasoning Paste & $2.075^{\mathrm{c}}$ & $0.9975^{\mathrm{cd}}$ & $1.9 \mathrm{~b}^{\mathrm{c}}$ \\
Final Drying & $0.3 \mathrm{~d}$ & $\mathrm{ND}$ & $0.6^{\mathrm{c}}$ \\
\hline LSD 0.05 & $\mathbf{0 . 9 6 3 1}$ & $\mathbf{1 . 3 8 1 7}$ & $\mathbf{1 . 4 5 2 0}$ \\
\hline
\end{tabular}

Mean values within a column followed with different superscripts are significantly different $(\mathrm{P}<0.05)$, ND: not detected.

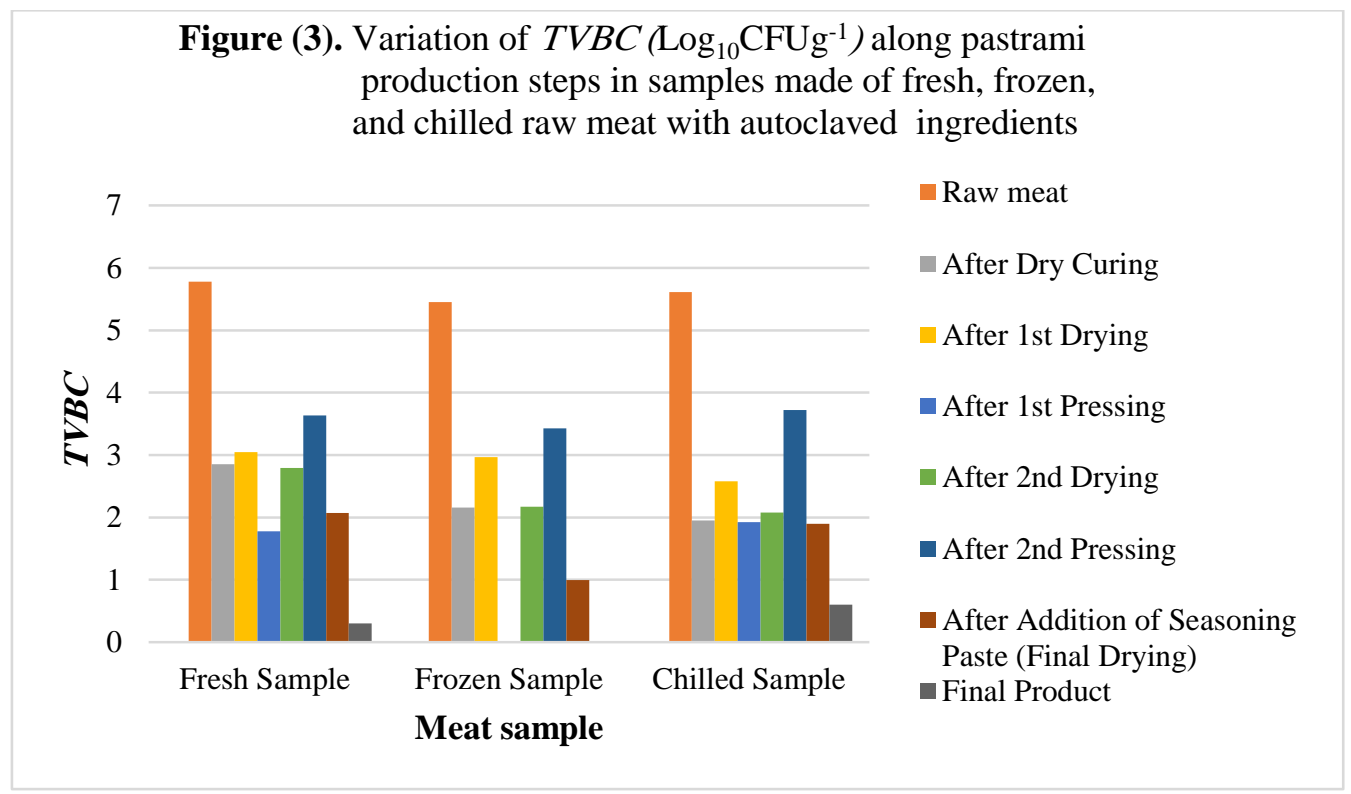

The data presented in Table (4) and Fig. (4) showed the E. coli strain count which is being undetectable after addition of dry curing mixture and during drying and pressing stages as it was confirmed with what reviewed by (Kaban, 2013) that the enterobacteriaceae do not stay alive during pastrami processing. The E. coli count is compatible with ESS (2005) as pastrami final product must be free from $E$. coli strains. 
Table (4). E.coli strains count $\left(\log _{10} \mathrm{CFUg}^{-1}\right)$ of pastrami product made of fresh, frozen, and chilled raw meat using autoclaved ingredients.

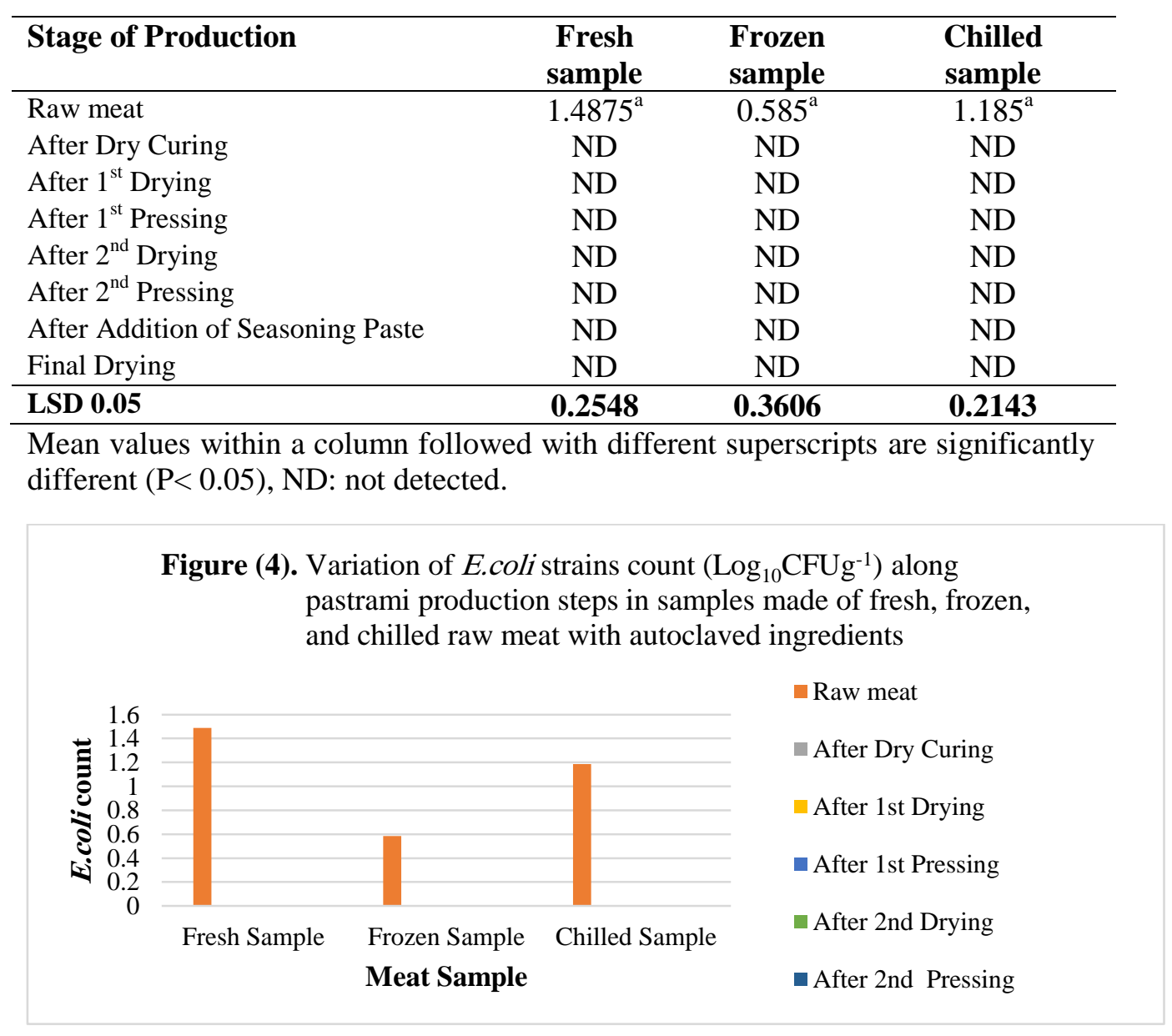

\section{Yeast and mold count:}

Yeast and mould count was calculated in final product in both microwaved and autoclaved groups. Data presented in Table (5) showed that there was a significant difference $(\mathrm{P}<0.05)$ in yeast count in autoclaved and microwaved manufactured pastrami groups. The yeast count of fresh final product was 1.4575 and $0.15 \log _{10} \mathrm{CFUg}^{-1}$ in microwaved and autoclaved groups respectively. The yeast count of frozen final product was 1.5125 $\log _{10} \mathrm{CFUg}^{-1}$ in microwaved final product and not detected in autoclaved final product. The yeast count of chilled final product was 1.785 $\log _{10} \mathrm{CFUg}^{-1}$ in microwaved final product and not detected in autoclaved final product. The best final product is autoclaved one as microwave 
Table (5).. Yeast and mould count $\left(\log _{10} \mathrm{CFUg}^{-1}\right)$ of pastrami final product made of fresh, frozen, and chilled raw meat with microwaved and autoclaved ingredients

\begin{tabular}{|c|c|c|c|c|c|c|}
\hline \multirow[t]{2}{*}{ Final Product } & \multicolumn{2}{|c|}{$\begin{array}{c}\text { Fresh } \\
\text { sample }\end{array}$} & \multicolumn{2}{|c|}{$\begin{array}{l}\text { Frozen } \\
\text { sample }\end{array}$} & \multicolumn{2}{|c|}{$\begin{array}{l}\text { Chilled } \\
\text { sample }\end{array}$} \\
\hline & $\mathrm{Y}$ & M & $\mathrm{Y}$ & M & $\mathrm{Y}$ & $M$ \\
\hline $\begin{array}{l}\text { Pastrami FP with } \\
\text { microwaved ingredients }\end{array}$ & $1.4575^{\mathrm{a}}$ & ND & $1.5125^{\mathrm{a}}$ & ND & $1.785^{\mathrm{a}}$ & ND \\
\hline $\begin{array}{l}\text { Pastrami FP with autoclaved } \\
\text { ingredients }\end{array}$ & $0.15^{\mathrm{b}}$ & ND & ND & ND & ND & ND \\
\hline LSD 0.05 & 0.4486 & - & 0.3684 & - & 0.3957 & - \\
\hline
\end{tabular}

Mean values within a column followed with different superscripts are significantly different $(\mathrm{P}<0.05)$, ND: Not detected, FP: Final product, Y: Yeast, M: Mould.

decontamination is less effective as previously discussed. Both microwaved and autoclaved final products are free from mould. This result is generally compatible with what reviewed by Kaban, (2013) that it was determined that yeast and mould counts are decreased during coating and final drying as it was reported that garlic which comprise $35 \%$ of seasoning paste has antimoulding effect.

\section{Aflatoxin estimation:}

Another group of pastrami was manufactured under complete sanitation using frozen meat imported from Brazil and divided into three treatments tested for presence of aflatoxins. The data presented in Table (6) illustrated that there was a significant difference $(\mathrm{P}<0.05)$ in aflatoxin level between the submitted three treatments.

The first treatment that produced without any spices showed low level of aflatoxins ( $8.5 \mathrm{ppb})$ which indicates that the raw meat imported from brazil itself contains a certain level of aflatoxin. The second treatment, which manufactured using unbridled spices bought from spice shops and decontaminated using autoclave at $120^{\circ} \mathrm{C}$ for $15 \mathrm{~min}$ showed high unacceptable limit of aflatoxin (41ppb) more than the acceptable limit which established by FDA (2000) to be 20ppb. Hence, it was found that the spices in second treatment participated in aflatoxin increase in pastrami final product by $32.5 \mathrm{ppb}$. This result indicates that the unbridled spices that purchased from ordinary spice shops contains aflatoxin that did not destructed by autoclaving. This is agreeable to what illustrated by Wannasawat and Vichai (2018). They illustrated that the aflatoxins need treatment by ultra-super steam $300-400^{\circ} \mathrm{C}$ for 10 to 80 seconds to be significantly decreased. The third treatment bought from hypermarket (spices were subjected to HACCP system application) and autoclaved. The 
Table (7). Sensory Evaluation of pastrami final product made of fresh, frozen, and chilled raw meat with autoclaved ingredients.

\begin{tabular}{lccccc}
\hline Sample & Taste & Odor & Texture & Color & $\begin{array}{c}\text { Overall } \\
\text { acceptability }\end{array}$ \\
\hline Fresh & $8.2^{\mathrm{a}}$ & $8.4^{\mathrm{a}}$ & $8.7^{\mathrm{a}}$ & $9^{\mathrm{a}}$ & $8.5^{\mathrm{a}}$ \\
Frozen & $8.2^{\mathrm{a}}$ & $7.9^{\mathrm{a}}$ & $7.9^{\mathrm{b}}$ & $7.3^{\mathrm{b}}$ & $7.8^{\mathrm{a}}$ \\
Chilled & $8.6^{\mathrm{a}}$ & $8.2^{\mathrm{a}}$ & $8.8^{\mathrm{a}}$ & $8.3^{\mathrm{a}}$ & $8.4^{\mathrm{a}}$ \\
\hline LSD 0.05 & $\mathbf{0 . 6 9 7 4}$ & $\mathbf{0 . 7 2 5 9}$ & $\mathbf{0 . 5 7 4 9}$ & $\mathbf{0 . 7 9 3 6}$ & $\mathbf{0 . 6 2 4 3}$ \\
\hline
\end{tabular}

Mean values within a column followed with different superscripts are significantly different $(\mathrm{P}<0.05)$.

It was revealed that autoclave sterilization is more efficient than microwave. This impact was so clear in pastrami final product from microbiological aspect. Moreover, spices was a hazardous source of aflatoxins and this was oblivious when pastrami final product tested for aflatoxins also meat contained a certain level of aflatoxin, which participated in final product aflatoxin content elevation. The pastrami final product in all samples was acceptable in terms of taste, odour, and overall acceptability. The pastrami final product made of frozen raw meat had lower evaluation in terms of colour and texture. This paper concluded that it is importance to decontaminate spices in meat industry as well as spices source tracking to get spices from reliable suppliers and of high quality subjected to quality programs. Figure (4) showed the flow chart of Egyptian pastrami production as well as detection of hazard type and necessity of applying prerequisite program including sanitation and personal hygiene in each step to control hazards.

\section{CONCLUSION}

It was clear that the ingredients addition in meat processing is an prominent source of contamination that heavily affect the final product. Therefore, it is recommended to select high quality ingredients with following-up personal hygiene and complete sanitary conditions. It is so important to track origins of materials and ingredients used during production process especially spices. This helps us controlling the microbial load and aflatoxin contents. To get antibacterial, antioxidant, and antifungal benefits from spices, spices must be subjected to HACCP measures in their production and recommended to be autoclaved at 120 for 15 minutes. Hence, spices addition is considered an essential CCP in pastrami manufacture. In pastrami manufacture as above mentioned, the higher the temperature during drying and pressing stages, the greater the bacterial count. Therefore, it is advisable to adjust temperature lower than $20^{\circ} \mathrm{C}$ to 
avoid bacterial count raising. In addition, it is advisable to add spices, plant extracts, and hot and sweet pepper puree in our modified recipe of seasoning paste to assist in $T V B C$ lowering during pastrami production.

Finally, It was revealed that the commitment to apply decontamination process for all ingredients, components, tools, and equipment as well as the guarantee to stratify staff aseptic terms and tracking the sources of used materials in manufacturing process are so essential matters to obtain high quality pastrami. This will lead us to follow-up the CCPs along the production course. Figure (5) showed the flow chart of dry-cured Egyptian pastrami.

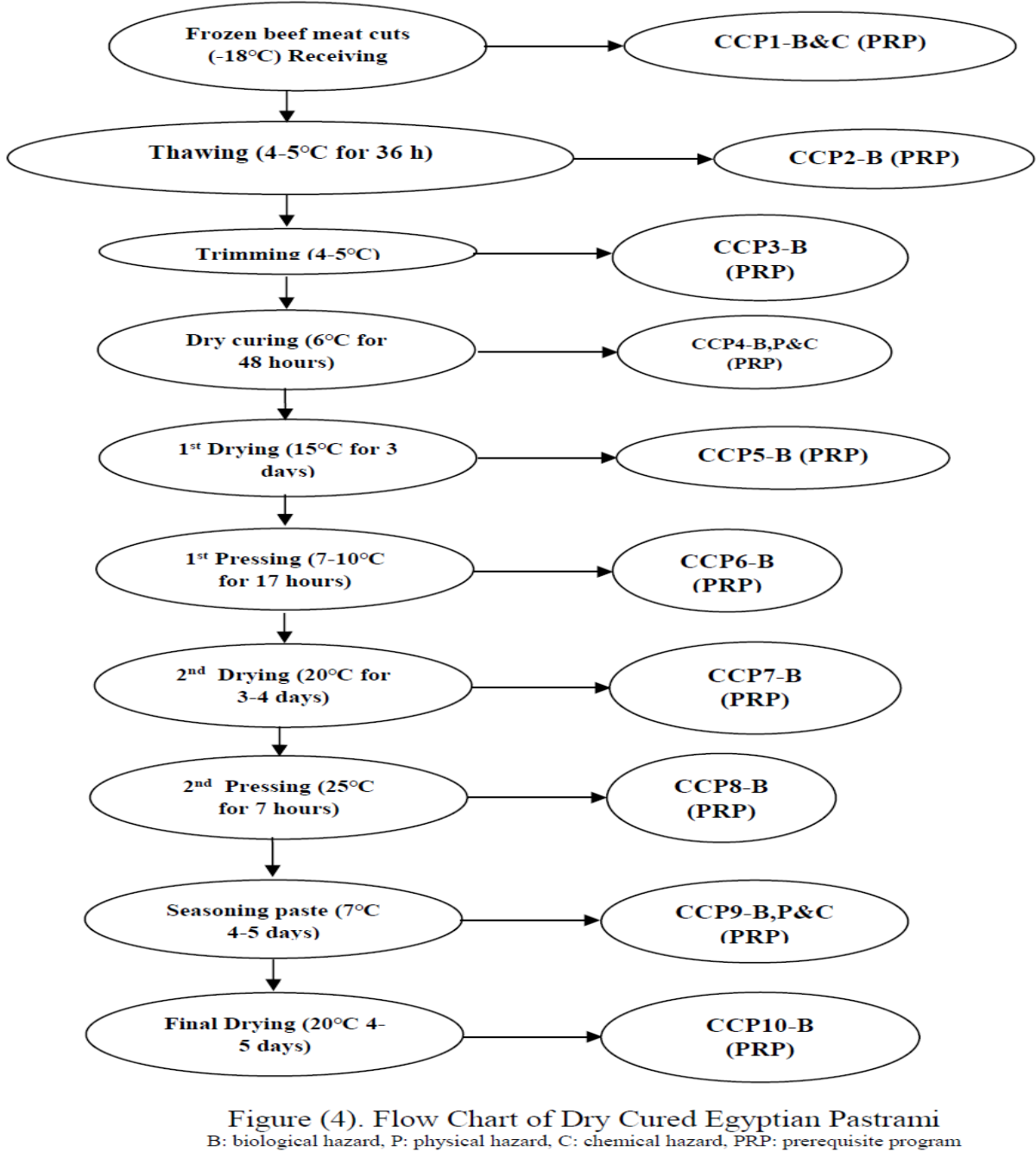




\section{REFERENCES}

Abd-Elghany, S. M. and Sallam, K. I. (2015). Rapid determination of total aflatoxins and ochratoxins $\mathrm{A}$ in meat products by immuno-affinity fluorimetry. Food chemistry, 179, 253-256.

Ahmet, A., Güzin, K., M. Murat, K. and Mükerrem, K. (2018). Characteristics of pastirma types produced from water buffalo Meat. Journal of the Faculty of Veterinary Medicine, Kafkas University, 24(2), 179-185.

Aksu, M. I., Erdemir, E. and Çakıcı, N. (2016). Changes in the physicochemical and microbial quality during the production of pastirma cured with different levels of sodium nitrite. Korean Journal for Food Science of Animal Resources, 36(5), 617.

Aksu, M. I., Dogan, M. and Sirkecioglu, A. N. (2017). Changes in the total lipid, neutral lipid, phospholipid and fatty acid composition of phospholipid fractions during pastırma processing, a dry-cured meat product. Korean Journal for Food Science of Animal Resources, 37(1) 18.

Aksu, M. I. and Kaya, M. (2001). Some microbiological, chemical and physical characteristics of pastırma marketed in Erzurum. Turkish Journal of Veterinary and Animal Sciences, 25(3), 319-326.

Aksu, M. I., Kaya, M. and Oz, F. (2008). Effect of Lactobacillus sakei and Staphylococcus xylosus on the inhibition of Escherichia coli O157: $H 7$ in pastirma, a dry- cured meat product. Journal of Food Safety, 28(1), 47-58.

Asefa, D. T., Kure, C. F., Gjerde, R. O., Langsrud, S., Omer, M. K., Nesbakken, T. and Skaar, I. (2011). A HACCP plan for mycotoxigenic hazards associated with dry-cured meat production processes. Food Control, 22(6), 831-837.

Barbara, A., Bevan, J., Greenway, S., Healy, B., McCurdy, S. M., Peutz, J. and Wittman, G. (2014). Acidification of garlic and herbs for consumer preparation of infused oils. Food Protection Trends, 34(4), 247-257.

Bibi, J. and Mahnoor, B. N. (2014). In-Vitro efficacy of crude extract of Zizipus Jujuba against selected bacterial strains. International Journal of Scientific and Research Publications, 4(2), 514.

Brodowska, A., Smigielski, K. and Nowak, A. (2014). Comparison of methods of herbs and spices decontamination. Chemik, 68(2), 97-102.

Canumir, J.A., Celis, J.E., de Bruijn, J. and Vidal, L.V., 2002. Pasteurisation of apple juice by using microwaves. LWT-Food Science and Technology 35, 389-392.

Daniela, R. and Adrian R. (2015). The Influnce of cyclic vaccuming and pressing process on tenderizing sheep pastrami. Scientific Research and Education in the Air Force-AFASES, 2.

Erdemir, E. and Aksu, M. İ. (2017). Changes in the composition of free amino acid during production of pastirma cured with different levels of sodium nitrite. Journal of Food Processing and Preservation, 41(2). 
ESS. (2005/1042). pastrami Egyptian Standard Specification Egyptian Organization for Standards and Quality (EOS), approved on 13/02/2005 and replaced the last version on 1991 (in Arabic).

FDA. (2000). Guidance for industry: action levels for poisonous or deleterious substances in human food and animal feed. USFDA, Washington, $D C$.

Hayes, P. and Forsythe, S. J. (2013). Food hygiene, microbiology and HACCP $\left(3^{\text {rd }}\right.$ Edition ed. Vol. Tota Viable Count (TVC)). UK: Springer Science and Business Media.

Ingham, S. C., Searls, G. and Buege, D. R. (2006). Inhibition of Salmonella serovars, Escherichia coli O157: H7 and Listeria monocytogenes during dry- curing and drying of meat: A case study with basturma. Journal of Food Safety, 26(2), 160-172.

Kaban, G. (2013). Sucuk and pastırma: Microbiological changes and formation of volatile compounds. Meat Science, 95(4), 912-918.

Karabıyıklı, Ş., Öncül, N. and Cevahiroğlu, H. (2015). Microbiological safety of pastrami: A traditional meat product. LWT-Food Science and Technology, 64(1), 1-5.

Kilic, B. (2009). Current trends in traditional Turkish meat products and cuisine. LWT-Food Science and Technology, 42(10), 1581-1589.

King, A. M., Glass, K. A., Milkowski, A. L., Seman, D. L. and Sindelar, J. J. (2016). Modeling the impact of ingoing sodium nitrite, sodium ascorbate, and residual nitrite concentrations on growth parameters of Listeria monocytogenes in cooked, cured pork sausage. Journal of Food Protection, 79(2), 184-193.

Ozturk, I. (2015). Presence, changes and technological properties of yeast species during processing of pastirma, a Turkish dry-cured meat product. Food Control, 50, 76-84.

Pandey, H. and Awasthi, P. (2015). Effect of processing techniques on nutritional composition and antioxidant activity of fenugreek (Trigonella foenum-graecum) seed flour. Journal of Food Science and Technology, 52(2), 1054-1060.

Panghal, A., Chhikara, N., Sindhu, N. and Jaglan, S. (2018). Role of food safety management systems in safe food production: A review. Journal of Food Safety, e12464 .https:// doi.org/10.1111/ jfs. 12464

Ray, F. K. (2004). Meat Curing. USA: Division of Agricultural Sciences and Natural Resources, Oklahoma State University.

Refai, M. K., Niazi, Z. M., Aziz, N. H. and Khafaga, N. E. M. (2003). Incidence of aflatoxin B1 in the Egyptain cured meat basterma and control by $\gamma$ - irradiation. Food/Nahrung, 47(6), 377-382.

Robach, M. C. and Sofos, J. N. (1982). Use of sorbates in meat products, fresh poultry and poultry products: A review. Journal of Food Protection, 45(4), 374-383.

Sharoba, A. (2009). Producing and evaluation of red pepper paste as new food product. Annals of Agric. Sci., Moshtohor, 47(2), 151-165.

Sullivan, G. A. (2011). Naturally cured meats: Quality, safety, and chemistry (A dissertation submitted to the graduate faculty in partial fulfillment of the requirements of the degree of Doctor Of Philosophy). Ames, Iowa, Iowa State University, USA. 
Wannasawat, P. and Vichai, R. (2018). Effect of ultra- superheated steam on aflatoxin reduction and roasted peanut properties. Journal of the Science of Food and Agriculture, 98, 2935-3941.

Wright, A. L., Hons, F. M., and Matocha Jr, J. E. (2005). Tillage impacts on microbial biomass and soil carbon and nitrogen dynamics of corn and cotton rotations. Applied Soil Ecology, 29(1), 85-92.

Yetim, H., Sagdic, O., Dogan, M. and Ockerman, H. W. (2006). Sensitivity of three pathogenic bacteria to Turkish cemen paste and its ingredients. Meat Science, 74(2), 354-358.

Zhao, Y., Flores, R. A. and OLSON, D. G. (1998). High hydrostatic pressure effects on rapid thawing of frozen beef. Journal OF Food Science, 63(2), 272-275.

\section{تأثير التعقيم باستخدام المايكرويف والأوتوكلاف على جودة البسطرمة وتثبّع نقاط التحكُّم الحرجة \\ رحمير عبدالغني عمد الموجيَ' - عبدالجواد محمد الثوَّاف' - عطيه محمد المخزنجي' - \\ ا ـ قسم علوم الأغذية والألبان - كلية التكنولوجيا والتنمية - جامعة الزقازيق -

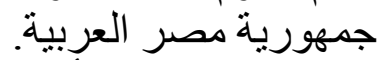 \\ r. قسم الرقابة على الأغذية ـ كلية الطب البيطري - جامعة المنصورة - جمهورية مصر العربية.}

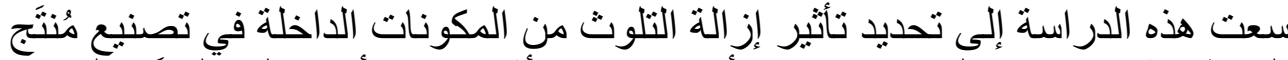

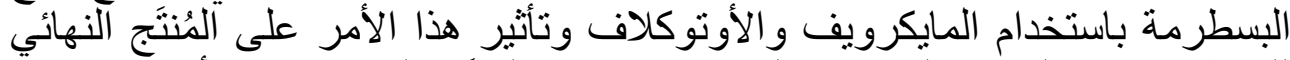

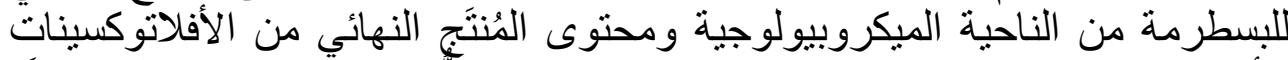

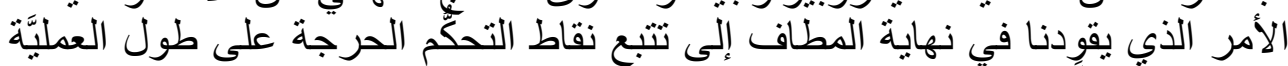

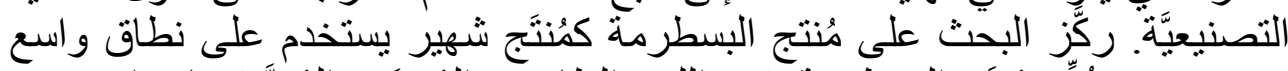

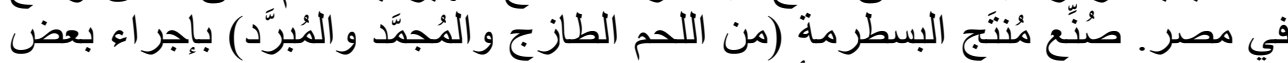

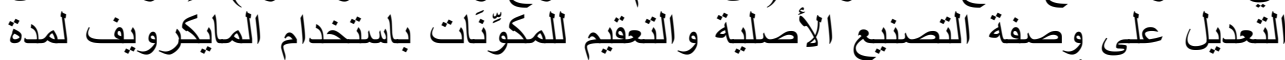

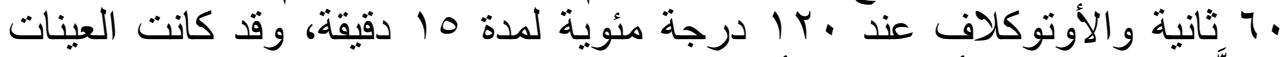

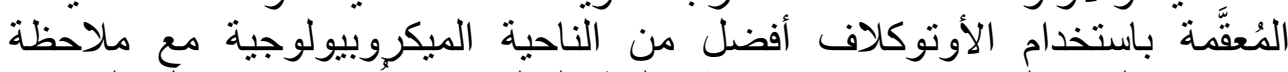

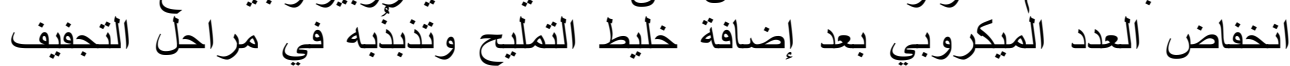

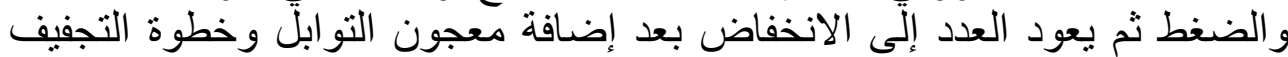

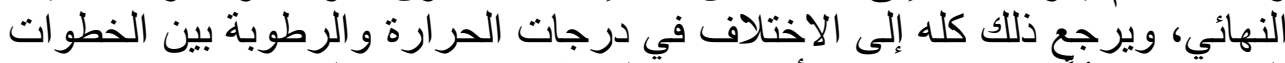

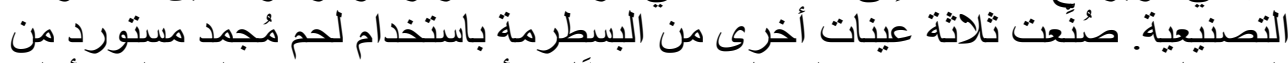

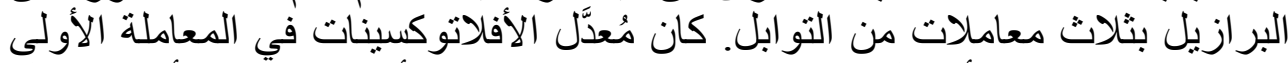

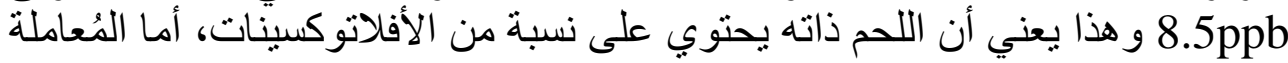


الثانية فكانت تحتوي على نسبة عالية جدًا (41ppb) مما يعني أن إضافة التوابل

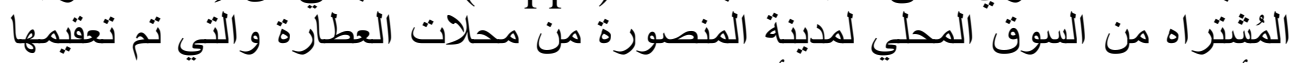

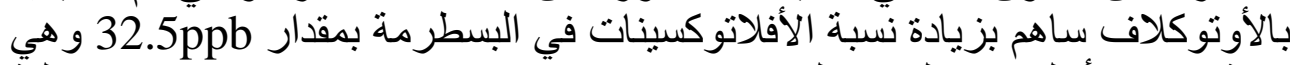

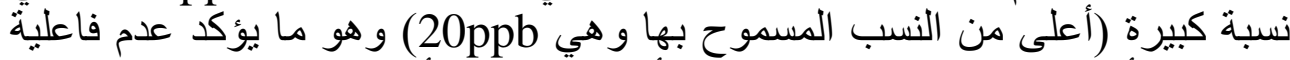

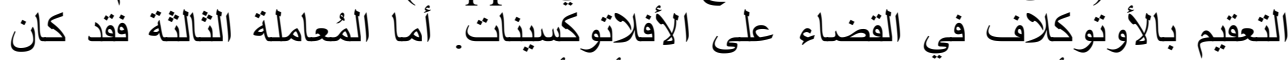

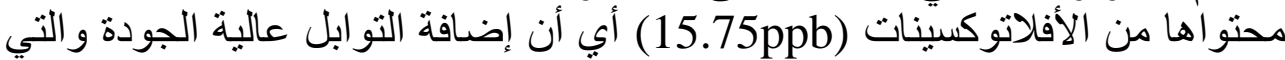

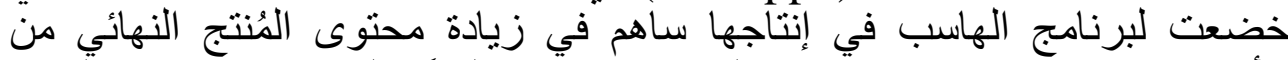

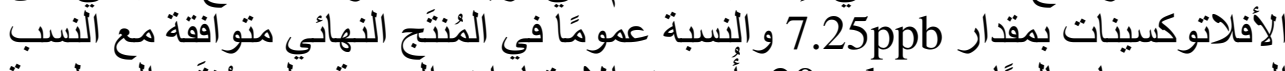

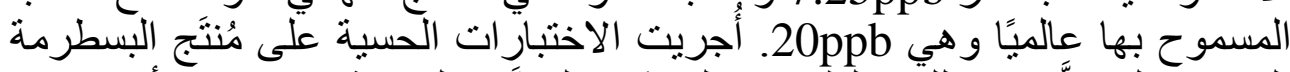

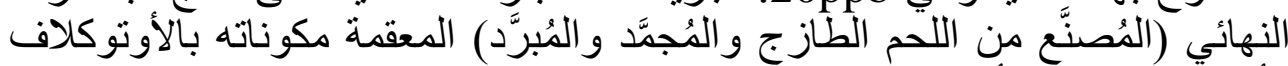

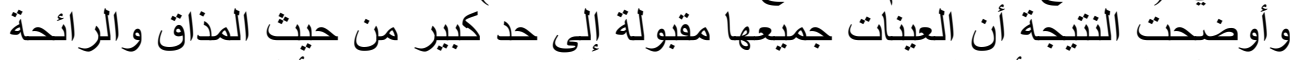

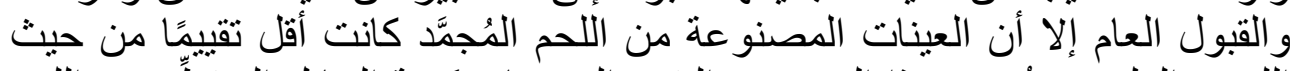

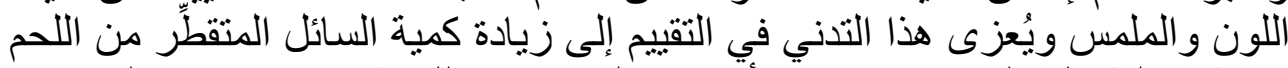

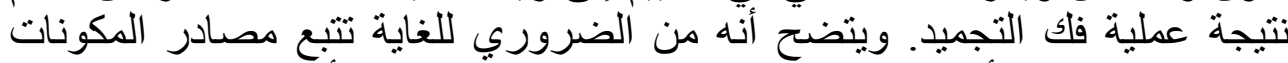

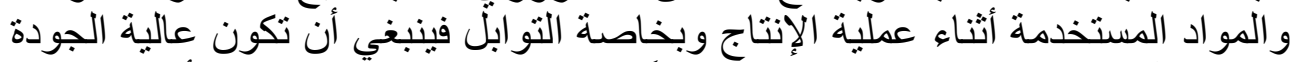

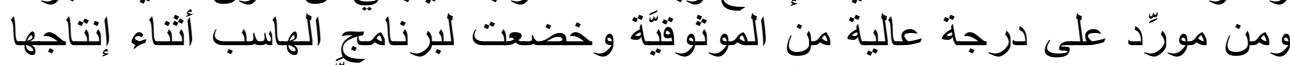

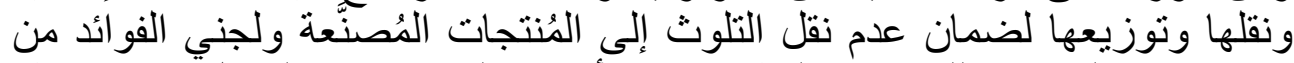

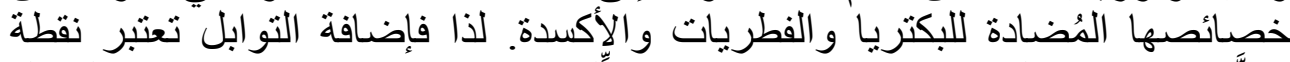

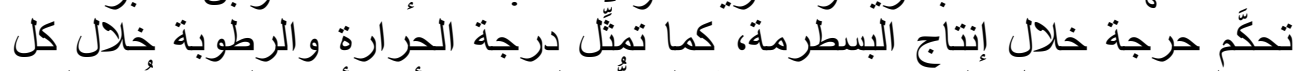

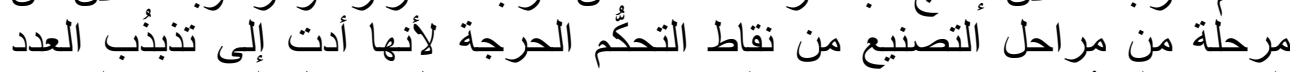

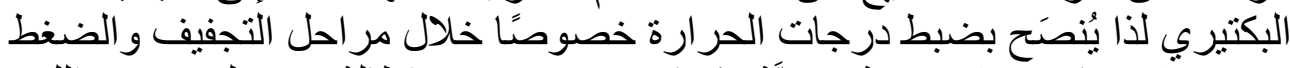

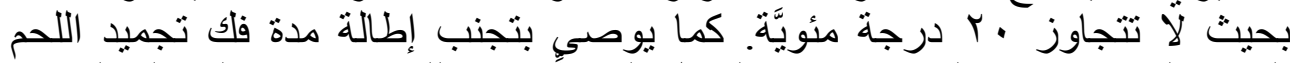

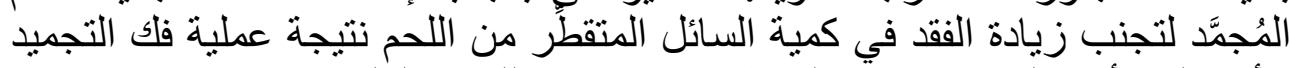

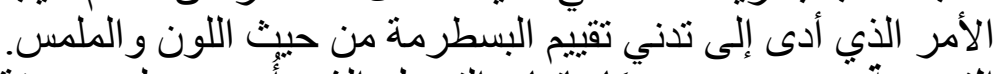

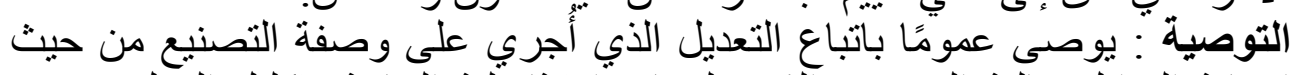

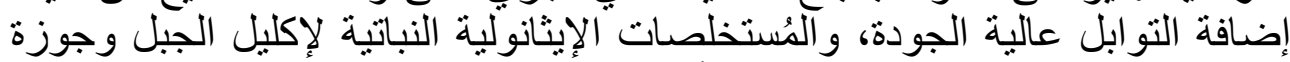

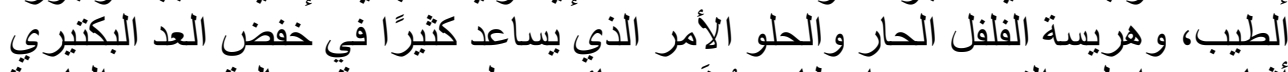

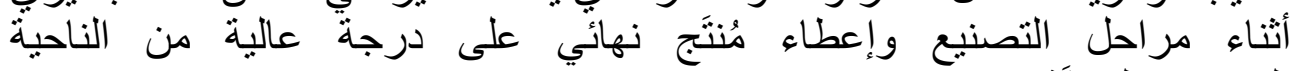
الميكروبيولوجيَّة.

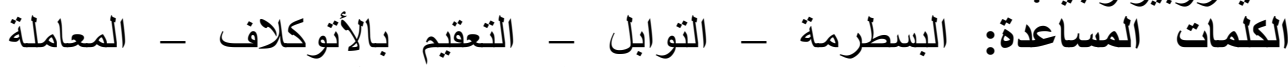
بالميكروييف ـ الخصائص الحسية ـ- الحمل الميكروبي. 